\title{
Possibility of increased general health related problems in women involved in beedi rolling
}

\section{Sir,}

Beedis is an indigenous cigarette filled with tobacco flake and wrapped in a tendu leaf, tied with a string at one end. Beedis accounted for about $73 \%$ of Indian tobacco consumption (Chaudhry K, Rath GK. Multisectoral and intersectoral approach to national tobacco control. Paper commissioned by the World Health Organization on the occasion of the WHO international conference on global tobacco control law: towards a WHO framework convention on tobacco control. 2000 Jan 7-9, New Delhi, India). Over three million Indians of whom are women are employed as beedi rollers as a cottage industry (http://en.wikipedia.org/wiki/Beedi). A single woman on an average rolls 1000 beedies per day, using around 500 grams of tobacco flake. A beedi roller may in the process inhale tobacco dust and other volatile components. ${ }^{1,2}$ India tops in beedi consumption, followed by other south East Asian countries. ${ }^{6}$ Beedis are also exported to western countries were they are marketed in various flavors and are popular among middle school and high school students. ${ }^{7}$ The popular belief among teenagers in the west is that beedi is herbal and hence cannot cause cancer. ${ }^{8}$

The procedure of beedi rolling involves curing of the tendu leaves drying them for 3 to 6 days and using them to wrap powdered tobacco. ${ }^{3,4}$ Furthermore, it has been reported that though beedi rolling have been classified as a hazardous work under the child labour prohibition and regulation act by the government of India 1.7 million children work as beedi rollers. ${ }^{1}$ According to report by the directorate general factory advice service and labour institutes (Government of India) health hazards among beedi rollers were due to two important reasons- hygienic and ergonomic factors. 5

\section{The hypothesis}

A number of studies have been conducted in the past to evaluate the general health status of beedi rollers. One such study involving 91 beedi rollers showed that 56.04 $\%$ had callosities on the dorsum of their fingers and feet, $72.72 \%$ had nail changes and infectious/non-infectious dermatoses in nearly $75 \%$ of the cases. ${ }^{9}$

Another study conducted in north Indian state of Bihar involving 197 female beedi rollers revealed that around $70 \%$ of them suffered from ophthalmological, neurological and gastrointestinal problems. More than $75 \%$ of them faced osteological problems. The total RBC, WBC and platelet counts of the beedi rollers were significantly lower when compared to control subjects. They also showed significantly high lymphocyte and eosinophil counts. They also showed lowered hemoglobin and elevated SGPT enzyme. The researchers concluded that beedi rolling may cause health hazards. ${ }^{10}$

In an Indian study involving beedi factory workers biological monitoring of tobacco processors exposed to tobacco particulate via nasopharyngeal and cutaneous roots, the researchers observed that the inspirable dust concentration was 150 times higher in such an environment. Increased levels of promutagens and direct acting mutagens was detected in workers' urine. A significant increase in chromosomal damage was noted in target and non-target cells of tobacco processors. ${ }^{11}$

In a cohort study on Italian involving cigarette factory worker the researchers concluded that the potential for exposure to pesticides should be carefully accounted for during tobacco manufacturing. ${ }^{12}$

Beedi rollers on an average handle 225-450 $\mathrm{g}$ of beedi tobacco per day and inhale tobacco dust and volatile components present in the work environment. ${ }^{13} \mathrm{~A}$ significant increase in DNA damage was observed in the beedi rollers working in confined environment as compared to those who worked in open and mixed kind of working conditions. ${ }^{14}$

A recent study on the socio economic aspect of the beedi rollers revealed that most beedi worker families earn about $\$ 6.40$ per 7-day work week, leaving them below the poverty line. The study also revealed that a vast majority of beedi workers are women and children, classified as unpaid assistants, who toil long hours in toxic environments. ${ }^{14}$

\section{CONCLUSION}

From the data available from all these studies we believe that health status of the beedi rollers could be relatively poorer when compared to that of non-exposed individuals. Adding to the above problems are factors like poor nutrition and illiteracy indirectly leading to further deterioration of health. 
Divya Hegde*, Priya Kamath

Department of Obstetrics and Gynecology, AJ Institute of Medical Sciences, Mangalore-575004, Karnataka, India

*Correspondence to: Dr. Divya Hegde,

E-mail: drshishirshettyomr@yahoo.com

\section{REFERENCES}

1. Yen KL, Hechavarria E, Bostwick SB. Beedi cigarettes: an emerging threat to adolescent health. Arch Pediatr Adolesc Med. 2000;154:1187-9.

2. Mahimkar MB, Bhisey RA. Occupational exposure to beedi tobacco increases chromosomal aberrations in tobacco processors. Mutat Res. 1995;334:139-44.

3. Lal P. Beedi: a short history. Curr Sci. 2009;96:1335-7.

4. Gupta PC, Hamner JE, Murthi PP. Global aspects of tobacco use and its implications for oral health. In: Gupta PC, Hamner JE, Murthi PP, eds. Control of Tobacco Related Cancers and Other Diseases. 1st ed. Bombay: Oxford University Press; 1992: 47-56.

5. Gosh PC, Iqbal R, Bairwa BL, Roychoudhury IK, Chandra S. Occupational health profile of the beedi workers and ergonomic intervention. Indoshnews 2005;10(2):1-7.

6. Prokhorov AV, Winickoff JP, Ahluwalia JS, OssipKlein D, Tanski S, Lando HA, et al. Youth tobacco use: a global perspective for child health care clinicians. Pediatrics. 2006;118(3):890-903.

7. Wu W, Song S, Ashley DL, Watson CH. Assessment of tobacco-specific nitrosamines in the tobacco and mainstream smoke of Beedi cigarettes. Carcinogenesis. 2004;25(2):283-7.
8. Watson CH, Polzin GM, Calafat AM, Ashley DL. Determination of tar, nicotine, and carbon monoxide yields in the smoke of beedi cigarettes. Nicotine Tob Res. 2003;5:747-53.

9. Kuruvila M, Mukhi SV, Kumar P, Rao GS, Sridhar KS, Kotian MS. Occupational dermatoses in beedi rollers. Indian J Dermatol Venereol Leprol. 2002;68:10-2.

10. Shahla Y, Basri A, Bushra H, Doris D. Occupational health hazards in women beedi rollers in Bihar, India. Bull Environ Contamin Toxicol. 2010;85(1):87-91.

11. Bhisey RA, Bagwe AN, Mahimkar MB, Buch SC. Biological monitoring of beedi industry workers occupationally exposed to tobacco. Toxicol Lett. 1999;108:259-65.

12. Settimi L, Costellati L, Naldi M, Bersani G, Olanda $\mathrm{S}$, Maiozzi P. Mortality among workers in an Italian cigarette factory. Occup Med. 1999;49:361-4.

13. Govekar RB, Bhisey RA. Elevated urinary thioether excretion among beedi rollers exposed occupationally to processed tobacco. Int Arch Occup Environ Health. 1992;64:101-4.

14. Shukla P, Khanna A, Jain SK. Working condition: a key factor in increasing occupational hazard among beedi rollers: a population health research with respect to DNA damage. Indian J Occup Environ Med. 2011;15:139-41.

15. Roy A, Efroymson D, Jones L, Ahmed S, Arafat I, Sarker R, et al. Gainfully employed? An inquiry into beedi-dependent livelihoods in Bangladesh. Tob Control. 2012;21:313-7.

DOI: $10.5455 / 2320-1770 . i j r \operatorname{cog} 20140929$

Cite this article as: Hegde D, Kamath P. Possibility of increased general health related problems in women involved in beedi rolling. Int $\mathrm{J}$ Reprod Contracept Obstet Gynecol 2014;3:870-1. 